\title{
Diversity and phylogenetic analyses of bacteria from a shallow-water hydrothermal vent in Milos island (Greece)
}

\section{Donato Giovannelli ${ }^{1,2,3 *}$, Giuseppe $d^{\prime}$ Errico $^{3}$, Elena Manini ${ }^{3}$, Michail Yakimov $^{4}$ and Costantino Vetriani ${ }^{1,2 *}$}

1 Department of Biochemistry and Microbiology, Rutgers University, New Brunswick, NJ, USA

2 Institute of Marine and Coastal Sciences, Rutgers University, New Brunswick, NJ, USA

${ }^{3}$ Institute for Marine Science - ISMAR, National Research Council of Italy - CNR, Ancona, Italy

${ }^{4}$ Institute Coastal Marine Environment-IAMC, National Research Council of Italy - CNR, Messina, Italy

\section{Edited by:}

Anna-Louise Reysenbach, Portland State University, USA

\section{Reviewed by:}

Karine Alain, Centre National de la Recherche Scientifique, France Casey R. J. Hubert, Newcastle University, UK

*Correspondence:

Donato Giovannelli, Institute for Marine Science - ISMAR, National Research Council of Italy - CNR, Largo Fiera della Pesca 60125, Ancona, Italy

e-mail: d.giovannelli@an.ismar.cnr.it; Costantino Vetriani, Institute of Marine and Coastal Sciences, Rutgers University, 71 Dudley Road, New Brunswick, NJ 08901, USA e-mail: vetriani@marine.rutgers.edu
Studies of shallow-water hydrothermal vents have been lagging behind their deep-sea counterparts. Hence, the importance of these systems and their contribution to the local and regional diversity and biogeochemistry is unclear. This study analyzes the bacterial community along a transect at the shallow-water hydrothermal vent system of Milos island, Greece. The abundance and biomass of the prokaryotic community is comparable to areas not affected by hydrothermal activity and was, on average, $1.34 \times 10^{8}$ cells $\mathrm{g}^{-1}$. The abundance, biomass and diversity of the prokaryotic community increased with the distance from the center of the vent and appeared to be controlled by the temperature gradient rather than the trophic conditions. The retrieved 16S rRNA gene fragments matched sequences from a variety of geothermal environments, although the average similarity was low (94\%), revealing previously undiscovered taxa. Epsilonproteobacteria constituted the majority of the population along the transect, with an average contribution to the total diversity of $60 \%$. The larger cluster of $16 \mathrm{~S}$ rRNA gene sequences was related to chemolithoautotrophic Sulfurovum spp., an Epsilonproteobacterium so far detected only at deep-sea hydrothermal vents. The presence of previously unknown lineages of Epsilonproteobacteria could be related to the abundance of organic matter in these systems, which may support alternative metabolic strategies to chemolithoautotrophy. The relative contribution of Gammaproteobacteria to the Milos microbial community increased along the transect as the distance from the center of the vent increased. Further attempts to isolate key species from these ecosystems will be critical to shed light on their evolution and ecology.

\section{Keywords: bacteria, Epsilonproteobacteria, shallow-water hydrothermal vent, Milos, geothermal}

\section{INTRODUCTION}

Microbes are one of the most abundant life forms on Earth, they are ubiquitous, possess a great metabolic plasticity and drive major biogeochemical cycles (Staley and Reysenbach, 2002). Studies carried out in geothermal and extreme environments have shown that life on Earth is far more diverse, widespread, and resistant to extreme conditions than previously thought. Despite the crucial roles of prokaryotes in extreme ecosystems, our understanding of their diversity and ecological relevance in these environments is limited.

Deep-sea hydrothermal vent ecosystems are largely based on chemolithoautotrophic primary production (Jannasch, 1985; Bach et al., 2006; Nakagawa and Takai, 2008). Photoautotrophic contribution to these ecosystems is limited to the sinking of low-quality particulate material from the photic zone (Comita et al., 1984). In contrast, shallow-water hydrothermal vent systems (located at depth $<200 \mathrm{~m}$ ) are largely influenced by photosynthesis (Tarasov et al., 2005). In these environments, chemolithoautotrophy and photoautotrophy occur simultaneously and spatial separation is often influenced by steep thermal and geochemical gradients (Wenzhöfer et al., 2000).

Shallow-water hydrothermal vents are widespread ecosystems that have been previously understudied compared to their deep-sea counterparts (InterRidge vents database, http://www. interridge.org/), despite the fact that these systems were known long before the discovery of the deep-sea vents on the Galapagos Rift in 1977 (Lonsdale, 1977). Because of their proximity to the surface, shallow-water hydrothermal systems are influenced both by geothermally generated reducing power and by light, and can be described as "high energy" environments, where microbial metabolism is fueled by different energy sources (Baross and Hoffman, 1985). According to Dando et al. (1995, 2000), the emission of carbon dioxide from the Milos venting area alone $\left(35 \mathrm{~km}^{2}\right)$ could account for $10 \%$ of the carbon dioxide emission caused by the venting associated with the Mid-Oceanic Ridges. It has been suggested that the conditions found in shallow-water hydrothermal systems could resemble those in which life originated and where metabolic divergence begun (Nisbet and Fowler, 1996; Nisbet and Sleep, 2001; Martin et al., 2008). 
Understanding the microbiology of shallow-water hydrothermal vents is necessary to evaluate how microorganisms influence biogeochemical cycles. The geology and chemistry of the hydrothermal system located in Paleochori Bay, a sandy bay off the South East coast of the island of Milos, was previously investigated by Dando et al. (2000) and Valsami-Jones et al. (2005). In Paleochori Bay, the vents are located in shallow waters, with temperatures ranging from 25 to $119^{\circ} \mathrm{C}$ (Botz et al., 1996) and extensive gas and fluid seepage. Early microbiological studies based on fingerprinting approaches showed the presence of bacteria associated to the Cytophaga-Flavobacteria-Bacteroides as well as Arcobacter spp. (Epsilonproteobacteria) and Thiomicrospira spp. (Gammaproteobacteria) (Brinkhoff et al., 1999; Sievert et al., 1999a, 2000a,b).

In this study, we carried out an environmental survey of a shallow-water hydrothermal vent located in Paleochori bay, Milos island, Greece. The site was sampled to investigate the structure and diversity of the bacterial community along a $1.5 \mathrm{~m}$ transect starting at the center of one of the vents.

\section{MATERIALS AND METHODS \\ SITE DESCRIPTION AND SAMPLE COLLECTION}

The Milos hydrothermal system is one of the largest in the Mediterranean Sea. It is part of the Hellenic Arc, whose eastern section reaches the Turkish coast and the island of Kos, and
Methana to the west. Extensive submarine venting occurs offshore, from the intertidal zone to depths of more than $100 \mathrm{~m}$, with an approximate extension of $34 \mathrm{~km}^{2}$ of seabed (Dando et al., 2000).

Inside the Paleochori bay (Figure 1), the venting area is characterized by strong degassing activities coupled with fluid seepage (Valsami-Jones et al., 2005). The entire shallow venting area is surrounded by patches of the seagrass Posidonia oceanica, and the vents occur as areas of high temperature and degassing on the sandy bottom (referred to hereafter as the center of the vent) that gradually decrease to ambient conditions as the distance from the vent increases. Steep thermal and redox gradients occur vertically, with temperature increasing with the depth of the sediment, while more gradual temperature and redox changes occur horizontally as the distance from the center of the vent increases (Sievert et al., 1999a, 2000a; Dando et al., 2000; Wenzhöfer et al., 2000). Temperatures of up to $119^{\circ} \mathrm{C}$ at a vent site in $10 \mathrm{~m}$ water depth have been reported (Botz et al., 1996). Venting fluids are enriched with freshwater with varying salinity. The composition of $\mathrm{CO}_{2}$ released with the fluids ranged between 54.9 and $91.9 \%$, while the concentrations of $\mathrm{H}_{2} \mathrm{~S}, \mathrm{CH}_{4}$ and $\mathrm{H}_{2}$ were $\leq 8.1, \leq 9.7$, and $\leq 3 \%$, respectively (Botz et al., 1996; Dando et al., 2000). In addition, the hydrothermal fluids have been shown to contain elevated concentrations of reduced inorganic chemicals, such as $\mathrm{NH}_{4}^{+}$(up to $1 \mathrm{mM}$ ), $\mathrm{H}_{2} \mathrm{~S}$ (up to $1 \mathrm{mM}$ ) and $\mathrm{Mn}^{2+}$ (up to $0.4 \mathrm{mM}$ )

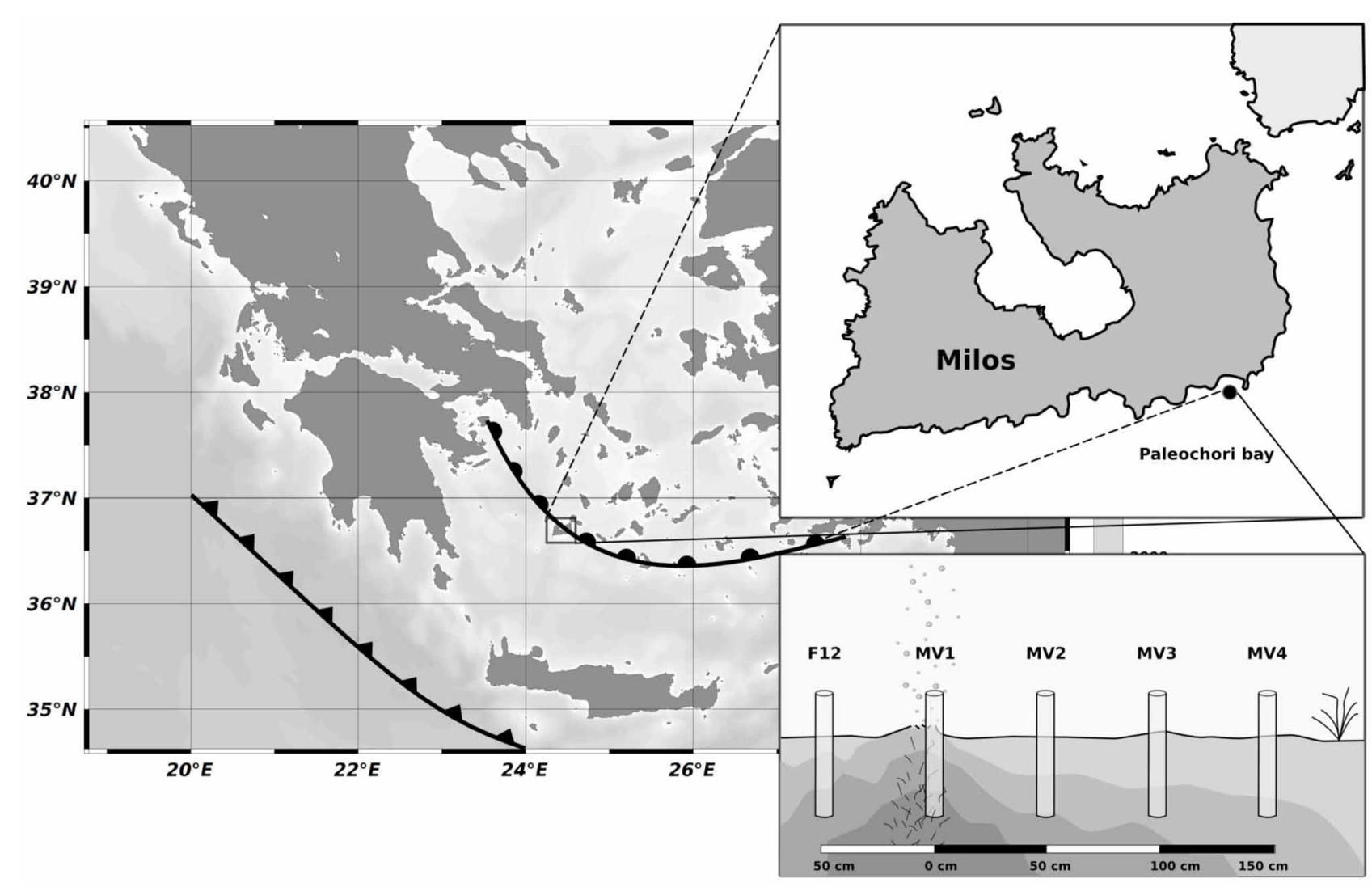

FIGURE 1 | Map showing the position of Milos (Greece) respect to the Hellenic back-arc (circles) and Hellenic Fault (triangles), the location of Paleochori Bay and the sampling strategy along the transect. Cores were placed at interval of $50 \mathrm{~cm}$ moving away from the vent orifice. 
(Fitzsimons et al., 1997). Arsenic and sulfur precipitates are common in proximity to vent orifices, and dense brines can be found in sediment depressions (Dando et al., 2000).

SCUBA divers collected sediment samples using push-cores during the MAMBA cruise in 2010. Starting from the center of a vent located at a depth of $12 \mathrm{~m}$ (designated as MV1; $36^{\circ} 40.351^{\prime}$ $\mathrm{N}, 24^{\circ} 31.108^{\prime} \mathrm{E}$ ), a horizontal transect consisting of four stations located $50 \mathrm{~cm}$ apart from each other was sampled (MV1, $0 \mathrm{~cm}$ distance from the center of the vent; MV2, $50 \mathrm{~cm}$ distance; MV3, $100 \mathrm{~cm}$ distance; MV4, $150 \mathrm{~cm}$ distance; Figure 1 and Table 1). Additionally, a single station was sampled at ca. $50 \mathrm{~cm}$ from the center of the vent in a yellow sediment patch (F12). The transect was characterized by a $20^{\circ} \mathrm{C}$ thermal gradient $\left(45\right.$ and $25^{\circ} \mathrm{C}$ at stations MV1 and MV4, respectively) and differences in sediment color were observed. Station MV4 appeared only marginally influenced by hydrothermal activity as the temperature of its surface sediments was close to ambient and P. oceanica was observed in close proximity (Table $\mathbf{1}$ ).

Cores were retrieved on board, sediment horizons separated $(0-1,3-5$, and $10-15 \mathrm{~cm})$ and processed according to the analytical procedure described in following paragraphs.

\section{ORGANIC MATTER COMPOSITION}

Aliquots of sediments were immediately frozen at $-20^{\circ} \mathrm{C}$ for determination of organic matter quantity and composition. Total protein concentrations were determined on sediment sub-samples according to Hartree (1972). Total carbohydrates were analyzed according to Gerchakov and Hatcher (1972) and expressed as glucose equivalents. Total lipids were extracted from the sediment by direct elution with chloroform:methanol (1:1 $\mathrm{v} / \mathrm{v}$ ) according to Bligh and Dyer (1959) and then determined according to Marsh and Weinstein (1966). All readings were performed spectrophotometrically. Carbohydrate, protein and lipid concentrations were converted into carbon equivalents using the conversion factors 0.40 and 0.49 and $0.75 \mathrm{mgC} \mathrm{mg}^{-1}$, respectively, and normalized to sediment dry weight (Fabiano et al., 1995). Biopolymeric organic carbon was calculated as the sum of the $\mathrm{C}$ equivalents of protein, lipid and carbohydrate.

Chlorophyll-a and phaeopigments were extracted from sediment sub-samples according to Plante-Cuny (1974). Briefly, a few mg of $\mathrm{MgCO}_{3}$ were added to $1 \mathrm{~g}$ of wet sediment to avoid chlorophyll-a degradation. Samples were supplemented with $90 \%$ acetone, sonicated and incubated in the dark at $4^{\circ} \mathrm{C}$ for $12 \mathrm{~h}$. Following incubation, the samples were centrifuged to remove the sediment and the concentration of the pigments in the supernatant were determined spectrofluorimetrically (ex. $430 \mathrm{~nm}$, em. $665 \mathrm{~nm}$ ) before and after acidification with $\mathrm{HCl} 0.1 \mathrm{~N}$. Concentrations were calculated against a standard curve and normalized to sediment dry weight. Total phytopigments (CPE) were obtained from the sum of chlorophyll-a and phaeopigments.

\section{PROKARYOTIC ABUNDANCE AND BIOMASS}

Total prokaryotic abundance was determined by direct counts after staining with acridine orange (Danovaro et al., 2002). Briefly, $0.5 \mathrm{~g}$ of each sample was supplemented with $5 \mathrm{mM}$ tetrasodium pyrophosphate and incubated for $15 \mathrm{~min}$ before sonication. The samples were then stained with $0.025 \%$ (wt/vol) acridine orange and filtered on $0.2 \mathrm{~mm}$ pore-size Nucleopore black polycarbonate filters, under low vacuum $(<100 \mathrm{~mm} \mathrm{Hg})$. The filters were analyzed as described by Fry (1990), using epifluorescence microscopy (Zeiss Axioskop 2; $1000 \times$ magnification). The total prokaryotic abundance was normalized to sediment dry weight after desiccation.

Prokaryotic biovolume was estimated using the image analysis software Image (Schneider et al., 2012). Average carbon content was assumed to be $310 \mathrm{fg} \mathrm{C} \mu \mathrm{m}^{3}$ (Fry, 1990). The prokaryotic biomass (PBM) was normalized to sediment dry weight.

Table 1 | Sampled stations, temperature, organic matter content and main characteristic of the area.

\begin{tabular}{|c|c|c|c|c|c|c|c|c|}
\hline Station & $\begin{array}{l}\text { Sediment } \\
\text { depth } \mathbf{c m}\end{array}$ & $\begin{array}{l}\text { Surface } \\
\text { temperature }{ }^{\circ} \mathrm{C}\end{array}$ & $\begin{array}{l}\text { Protein } \\
\mathbf{m g ~ g}^{-1}\end{array}$ & $\begin{array}{l}\text { Carbohydrate } \\
\mathrm{mg} \mathrm{g}^{-1}\end{array}$ & $\begin{array}{l}\text { Lipids } \\
\text { mg g }^{-1}\end{array}$ & $\begin{array}{l}\text { BPC mg } \\
\mathrm{C} \mathrm{g}^{-1}\end{array}$ & $\begin{array}{l}\text { CPE } \\
\mu g^{-1}\end{array}$ & Notes \\
\hline \multirow[t]{2}{*}{ MV1 } & $0-1$ & 45 & $0.70 \pm 0.05$ & $0.07 \pm 0.00$ & $0.18 \pm 0.02$ & $0.45 \pm 0.03$ & $11.84 \pm 1.35$ & Vent orifice-dark gray sediment \\
\hline & $10-15$ & & $0.39 \pm 0.00$ & $0.12 \pm 0.02$ & $0.10 \pm 0.03$ & $0.29 \pm 0.03$ & $6.12 \pm 0.64$ & \\
\hline \multirow[t]{2}{*}{ MV2 } & $0-1$ & 32 & $0.53 \pm 0.15$ & $0.03 \pm 0.01$ & $0.10 \pm 0.01$ & $0.30 \pm 0.06$ & $9.31 \pm 0.94$ & \\
\hline & $10-15$ & & $0.88 \pm 0.63$ & $0.01 \pm 0.00$ & $0.14 \pm 0.01$ & $0.46 \pm 0.25$ & $2.14 \pm 0.51$ & \\
\hline \multirow[t]{2}{*}{ MV3 } & $0-1$ & 28 & $0.42 \pm 0.17$ & $0.05 \pm 0.01$ & $0.21 \pm 0.02$ & $0.34 \pm 0.09$ & $25.69 \pm 2.24$ & Presence of white precipitate \\
\hline & $3-5$ & & $0.10 \pm 0.05$ & $0.02 \pm 0.00$ & $0.09 \pm 0.02$ & $0.12 \pm 0.01$ & $11.37 \pm 0.38$ & \\
\hline MV4 & $0-1$ & 25 & $0.20 \pm 0.03$ & $0.08 \pm 0.03$ & $0.15 \pm 0.15$ & $0.23 \pm 0.08$ & $154.6 \pm 3.89$ & Proximity to $P$. oceanica \\
\hline
\end{tabular}

Means are reposted with standard deviation. BPC, Biopolymeric organic carbon; CPE, total phytopigments. 


\section{GENOMIC DNA EXTRACTION AND PCR AMPLIFICATION}

Genomic DNA was extracted from sediment biomass by the phenol:chloroform method (Maniatis, 1989). Briefly, aliquots of frozen sediments (ca. $0.5 \mathrm{~g}$ ) were resuspended in extraction buffer ( $100 \mathrm{mM}$ Tris-HCL, $100 \mathrm{mM}$ EDTA, $1.5 \mathrm{M} \mathrm{NaCl}$ $\mathrm{pH}$ 8.0), supplemented with $10 \mathrm{mg} \mathrm{ml}^{-1}$ lysozyme and incubated for $30^{\prime}$ at $37^{\circ} \mathrm{C}$. Subsequently, 20\% SDS was added and each sample was incubated with agitation for $1 \mathrm{~h}$ at $60^{\circ} \mathrm{C}$. Sediments were removed by centrifugation $(5 \mathrm{~min}$ at $14,000 \times \mathrm{g}$ ) and supernatants were collected and extracted with 1 volume of phenol:chloroform:isoamyl alcohol (25:24:1) followed by one extraction with chloroform:isolamyl alcohol (24:1). DNA was then precipitated overnight with 0.1 volumes of sodium acetate and 0.7 volumes isopropanol, washed with $70 \%$ ice-cold ethanol, resuspended in PCR grade water and visualized on 1\% agarose gel.

The bacterial 16S rRNA gene was amplified by polymerase chain reaction (PCR) using universal bacterial primer $8 \mathrm{~F}\left(5^{\prime}\right.$ AGA GTT TGA TCC TGG CTC AG-3') and 1517R (5'-ACG GCT ACC TTG TTA CGA CTT-3') (Weisburg et al., 1991). Aliquots of $5 \mu \mathrm{l}$ of PCR products were visualized by staining with ethidium bromide on $1.5 \%$ agarose gel.

\section{DENATURING GRADIENT GEL ELECTROPHORESIS}

A preliminary assessment of the diversity of the sediment bacterial communities was carried out by Denaturing Gradient Gel Electrophoresis (DGGE) analysis of the bacterial 16S rRNA gene. The full-length 16S rRNA gene was obtained as described above, gel-purified and used as a template for nested PCR to amplify the $\mathrm{V} 3$ region using the GC-clamp primer $338 \mathrm{~F}-(\mathrm{GC})\left(5^{\prime}\right.$-CGC CCG CCG CGC GCG GCG GGC GGG GCG GGG GCA CGG GGG GAC TCC TAC GGG AGG CAG CAG-3') and 519R (5'GWA TTA CCG CGG CKG CTG-3'). DGGE was performed with a D Gene system (Bio-Rad Laboratories, Hercules, CA). PCR products $(15 \mathrm{ml})$ were applied directly onto $6 \%$ (wt/vol) polyacrylamide gels in $1 \times$ TAE $(0.04 \mathrm{M}$ Tris base, $0.02 \mathrm{M}$ sodium acetate, $1 \mathrm{mM}$ EDTA pH 7.4), with denaturant gradient from 40 to $60 \%$ (where $100 \%$ denaturant contains $7 \mathrm{M}$ urea and $40 \%$ formamide). Electrophoresis was performed at a constant voltage of $45 \mathrm{~V}$ for $14 \mathrm{~h}$. After electrophoresis, the gels were incubated for $15 \mathrm{~min}$ in $0.5 \mathrm{mg} \mathrm{l}^{-1}$ ethidium bromide, rinsed for $10 \mathrm{~min}$ in distilled water, and photographed with a UV Foto Analyst system (Fotodyne, Inc., Hartland, WI).

\section{LIBRARY CONSTRUCTION AND RFLP ANALYSIS}

Amplified 16S rRNA gene fragments were excised from agarose gels, purified, and cloned into the pCR2-TOPO vector using the TOPO-TA Cloning Kit (Invitrogen, Inc., Carlsbad, California) following the manufacturer's instructions. The resulting ligation products were used to transform competent Escherichia coli TOP10 cells. Recombinant E. coli clones were grown on LuriaBroth media supplemented with $100 \mu \mathrm{g} \mathrm{ml}^{-1}$ ampicillin. Sixty to ninety clones for each library were randomly chosen and analyzed for insert-containing plasmids by direct PCR followed by gel electrophoresis of the amplified products. Insert 16S rRNA gene fragments were digested with HaeIII and MspI (Promega, Inc., Madison, Wis.) restriction endonucleases for $3 \mathrm{~h}$ at $37^{\circ} \mathrm{C}$ and subjected to Restriction Fragment Length Polymorphism (RFLP) analysis on 3\% low-melting agarose gel. Clones were grouped into operational taxonomic units (OTUs) based on their RFLP profiles, and sequences (about 900 bases) were obtained from representative clones of each OTU.

\section{STATISTICAL AND PHYLOGENETIC ANALYSES}

Analysis of variance (ANOVA) using the statistical R-Software (R-Cran project, http://cran.r-project.org/) was carried out to identify significantly different samples, which were subjected to the Tukey HSD post-hoc test. Where ANOVA assumptions were rejected, a more conservative level of $p$ was chosen (Underwood, 1991). DGGE profiles were analyzed with ImageJ (Schneider et al., 2012) and R-software for cluster analysis to identify significant differences in the composition of bacterial communities. Briefly, the position of each DGGE band was recorded using the ImageJ Gel plugin and the resulting matrix was fed to $\mathrm{R}$ for the determination of the distance matrix based on Jaccard dissimilarity and used for cluster analysis.

Sequences obtained from libraries were manually checked for quality, primers were removed and the resulting sequences were aligned using ClustalW (Larkin et al., 2007) and SeaView (Gouy et al., 2010). The software Bellerophon (Huber et al., 2004) was used to identify chimeric sequences, which were removed from the dataset $(2.2 \%$ of total sequences were identified as chimeric). Neighbor-Joining trees were constructed using the Jukes-Cantor correction and tree topologies were tested using 1000 bootstraps replications (Perriere and Gouy, 1996). Sequences of cultured bacteria retrieved as top blast hits against our sequences were included as references in the alignment. Phylogenetic designation of the sequences to a specific group was obtained by integrating blastn and EzTaxon results with phylogenetic analyses (Chun et al., 2007). Chaol non-parametric diversity estimator and rarefaction curves were computed using Rarefaction software (http://www2.biology.ualberta.ca/jbrzusto/ rarefact.php).

The sequences from this study are available through GenBank under accession numbers from KC463698 to KC463741.

\section{RESULTS}

\section{SEDIMENTARY ORGANIC MATTER CONTENT}

Biopolymeric organic carbon (BPC) in the surface sediments decreased along the transect from the center of the vent (MV1) toward the background station (MV4) with values ranging from $0.45 \pm 0.03$ to $0.23 \pm 0.08 \mathrm{mg} \mathrm{C} \mathrm{g}^{-1}$ at station MV1 and station MV4, respectively (Table 1). At station F12, BPC was highest $\left(1.51 \pm 0.08 \mathrm{mg} \mathrm{C} \mathrm{g}^{-1}\right)$. The observed horizontal gradients were significant (ANOVA $p<0.001$ ), and a BPC minimum at a depth of $3-5 \mathrm{~cm}$ was observed at all stations. Proteins dominated the carbon pool at all stations with an average contribution to BPC of $55 \%$, followed by lipids and carbohydrates. Protein contribution to the carbon pool decreased along the transect from MV1 to MV4 (Table 1). In contrast, total phytopigment (CPE) concentration increased along the transect from MV1 to MV4 (ANOVA $p<0.001)$. Chlorophyll-a concentrations were extremely low, and phaeopigments were the most abundant class. The quantity and composition of the organic matter of the yellow surface 
sediments at station F12 differed from that of the other stations with proteins contributing nearly $95 \%$ of the BPC (Table 1).

\section{PROKARYOTIC ABUNDANCE AND BIOMASS}

In general, total prokaryotic abundance decreased as the depth of the sediment increased at all stations, despite their proximity to vent orifice (Figure 2A; ANOVA $p<0.001$ ). Values ranged from $0.8 \pm 0.4 \times 10^{8}$ to $2.7 \pm 1.1 \times 10^{8}$ cells $\mathrm{g}^{-1}$ in the surficial sediments for MV1 and MV4, respectively, indicating higher abundances in the surface sediment layers and an increasing trend along the transect from MV1 to MV4. These trends were statistically significant (ANOVA $p<0.001$ ). Prokaryotic biomass in surficial sediments ranged from $1.61 \pm 1.06$ to $11.95 \pm 6.3 \mu \mathrm{g}$ $\mathrm{C} \mathrm{g}^{-1}$ in station MV2 and MV4, respectively (Figure 2B). Again, a trend of decreasing biomass with increasing sediment depth and increasing biomass along the transect toward the periphery of the vent was observed (Figure 2B; ANOVA $p<0.01$ ).
Prokaryotic abundance in station F12 was comparable to station MV1, while prokaryotic biomass was significantly higher. The decreasing trend along the vertical sediment profile was more evident at stations located further away from the center of the vent. Inter-replicate variability was also higher at those stations.

\section{PROKARYOTIC DIVERSITY}

DGGE was used to investigate the diversity of the sediment bacteria from the $0-1,5-10$ and $10-15 \mathrm{~cm}$ layers along the transect stations, and that from the $0-1 \mathrm{~cm}$ layer of station F12 (Figure 3). Similar DGGE profiles were obtained from stations MV1, MV3 and MV4 and F12 (data were not obtained for station MV2). Cluster analysis based on the DGGE profiles indicated that the bacterial communities from the same sediment layers tend to group together (Figure 3). A relevant group included communities from the $0-1 \mathrm{~cm}$ sediments from the transect stations and from F12, while the 3-5 and 10-15 cm layers from MV1 and MV4
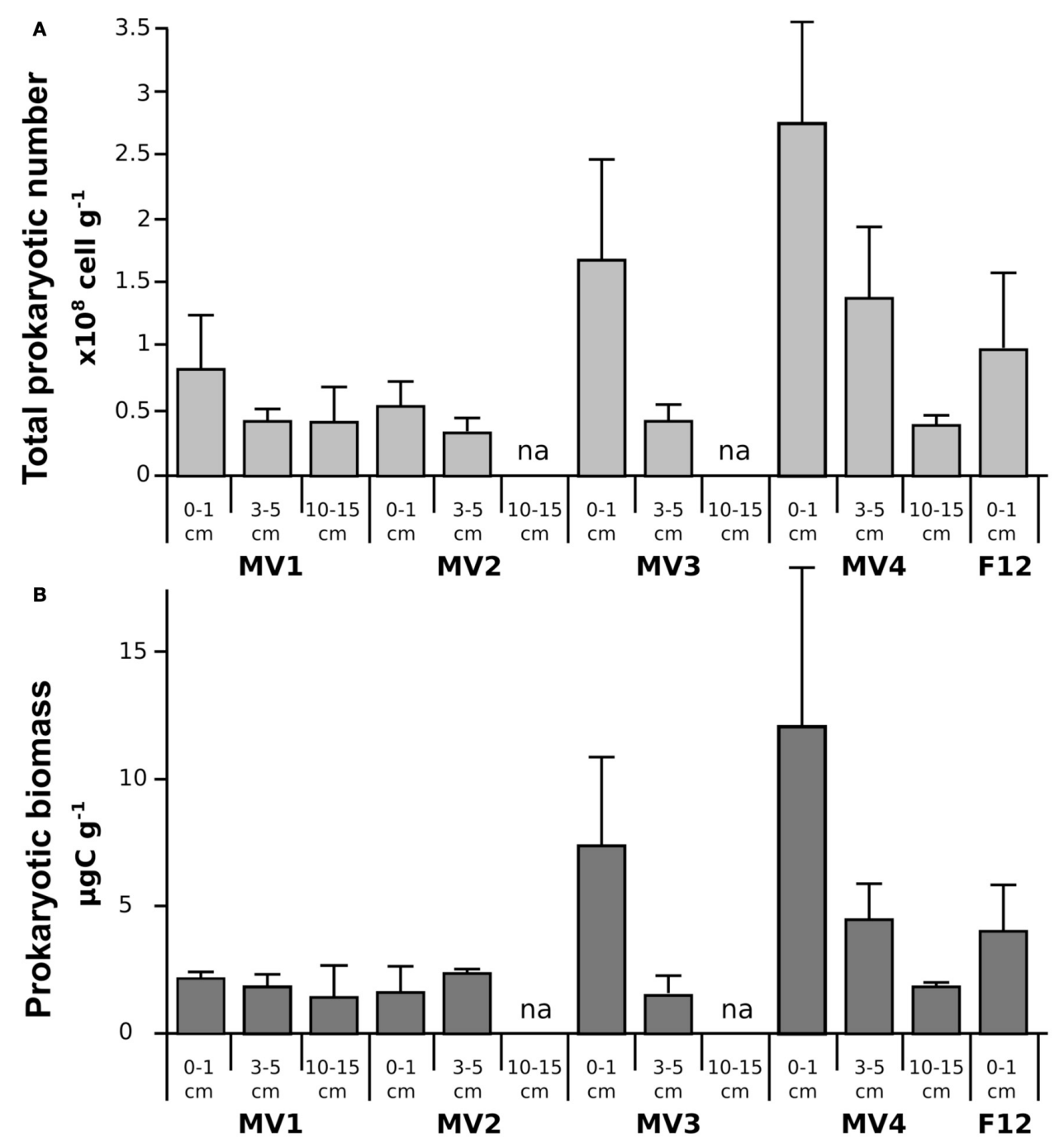

FIGURE 2 | Prokaryotic abundance (TPN; A) and biomass (PBM; B) along the sampled stations. Mean values are reported with standard deviation. na $=$ data not available. 


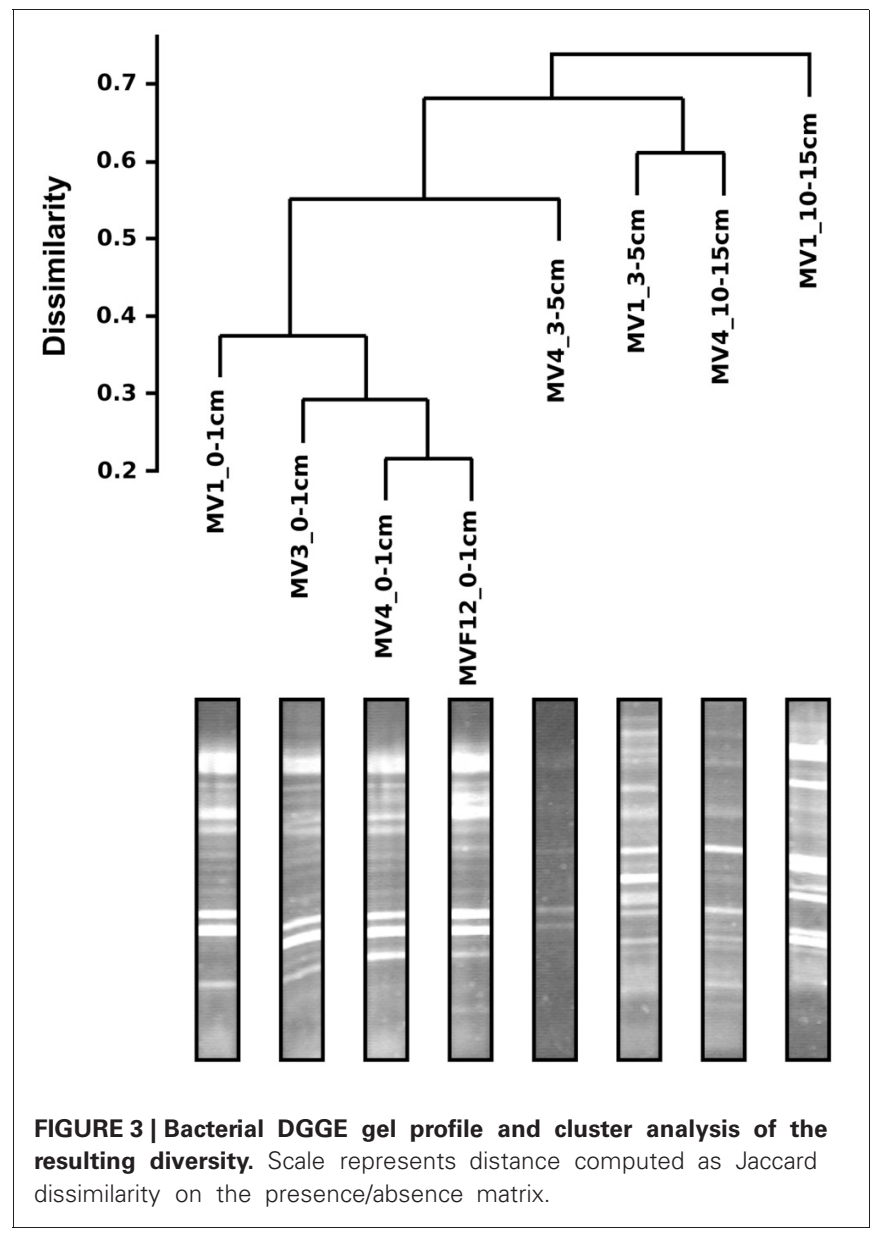

formed a second group (Figure 3). The bacterial communities from the $0-1 \mathrm{~cm}$ layer of stations MV1 (center of the vent) and MV4 (periphery of the vent) were selected to construct 16S rRNA gene libraries.

Both the MV1 and MV4 libraries were dominated by sequences that could be assigned to the Epsilonproteobacteria (60 and 59\% for MV1 and MV4, respectively; Figure 4). Other common phyla in both libraries were sequences belonging to the CFB (20 and 6\% for MV1 and MV4, respectively; Figure 4) and Gammaproteobacteria (7 and 20\% for MV1 and MV4, respectively; Figure 4). The number of gammaproteobacterial clones increased at the periphery of the vent and the ratio of Epsilonto Gammaproteobacteria was 8.2 and 2.9 at stations MV1 and MV4, respectively. Sequences related to the Deltaproteobacteria, Planctomycetes, Actinobacteria and Ignavibacteria were also found. Four percent of the sequences retrieved from station MV1 could not be assigned to any known lineage (Figure 4).

The sequences were further analyzed by aligning them against closest cultured relatives and a neighbor-joining tree was constructed (Figure 5). Both libraries are well represented in the tree, with numerous sequences clustering together despite their different origins. A large number of sequences obtained from the libraries were related to Sulfurovum lithotrophicum (Inagaki et al., 2004), and clustered around this sequence on the tree (average similarity of 93\%; Figure 5 and Table 2). The Sulfurovumrelated sequences were organized in two discrete clusters, each containing clones from both libraries, and represented 44\% of the clones in each library. The same clusters had best hits in the non-redundant database to sequences identified during environmental surveys in a variety of submarine geothermal

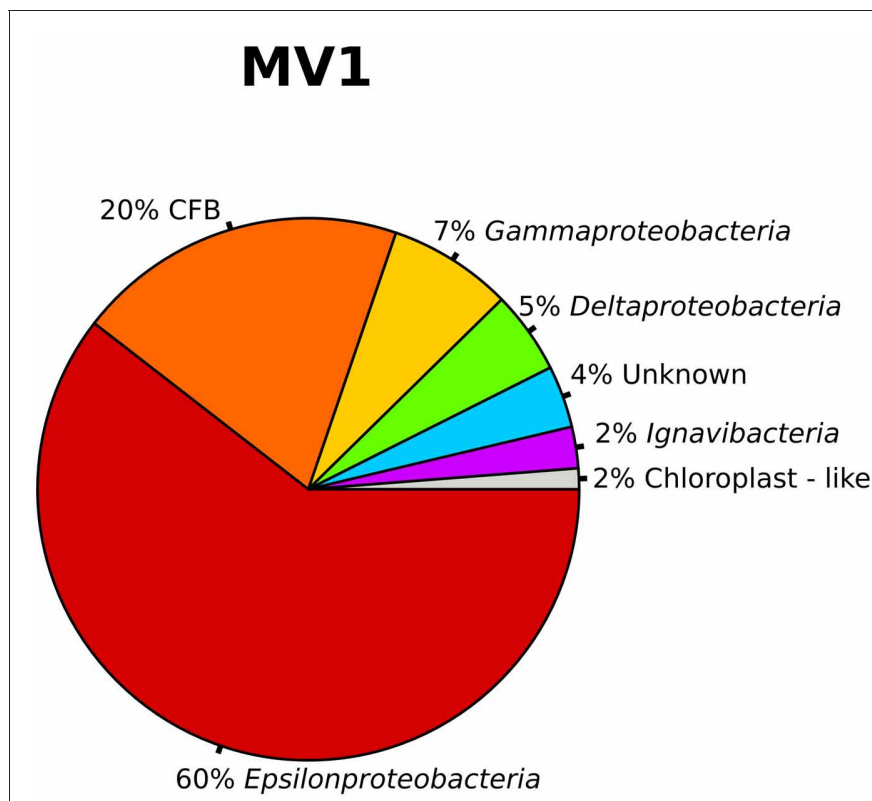

\section{MV4}

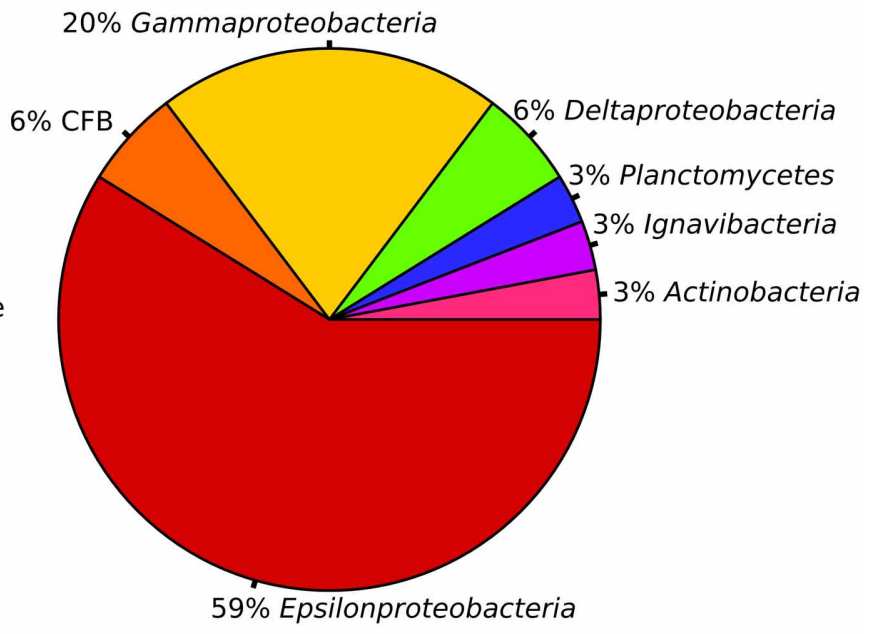

FIGURE 4 | Bacterial community structure at station MV1 and MV4 surface sediments (0-1 cm) as obtained by the analysis of the sequences. Groups are shown at the phylum level based on the results of BLAST and position on the phylogenetic tree. CFB, Cytophaga-Flavobacteria-Bacteroides group. 


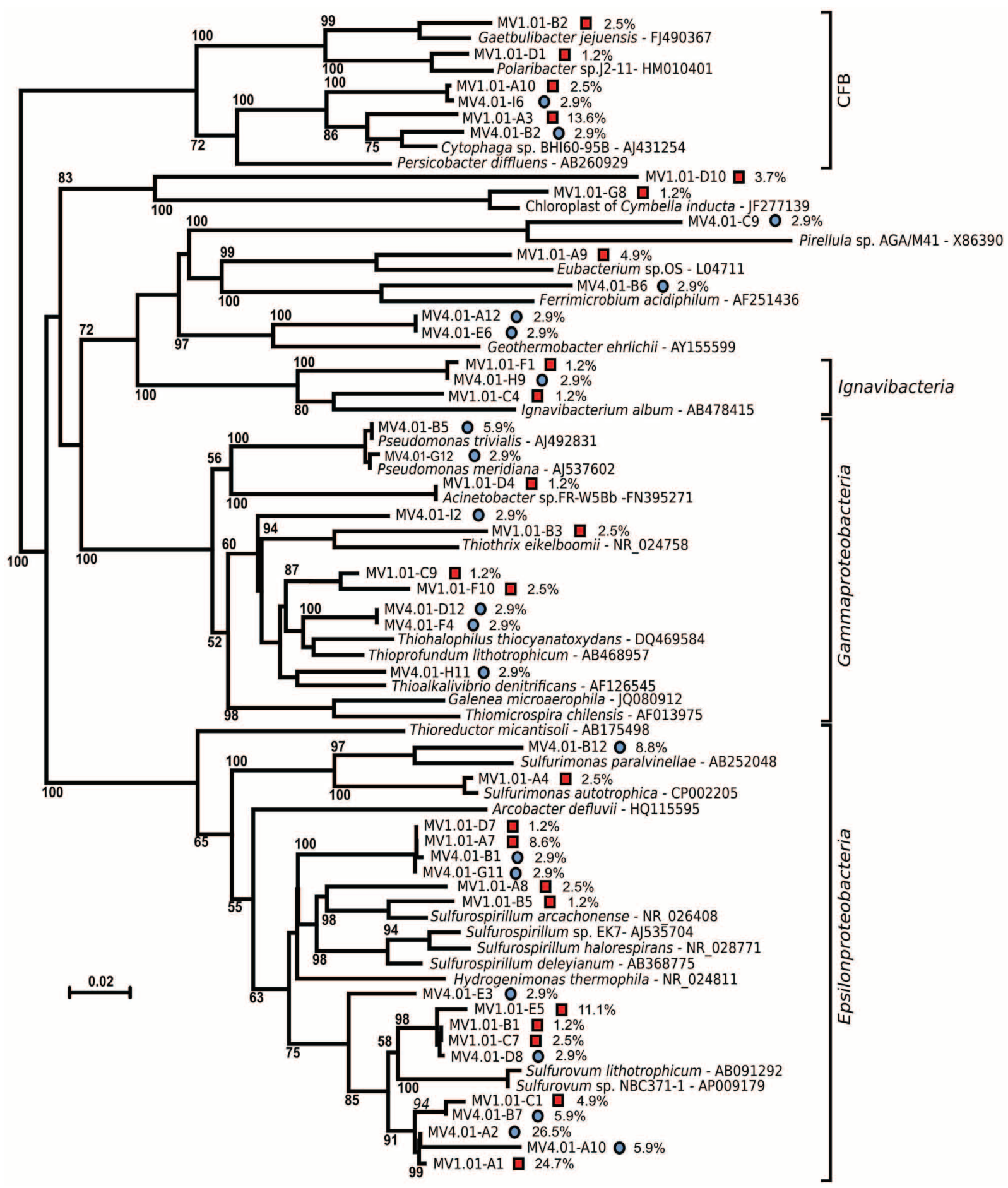

FIGURE 5 | Unrooted Neighbor-joining tree of the bacterial diversity at station MV1 (red squares) and MV4 (blue circles) surface sediments $(\mathbf{0}-\mathbf{1} \mathbf{c m})$ with cultured relatives. The tree was obtained using Jukes-Cantor correction and 1000 bootstrap. Bar, $2 \%$ substitution rate. Bootstrap values below 50 are not shown. Percent values refer to the abundance of individual clones in the libraries. CFB, Cytophaga-Flavobacteria-Bacteroides group. environments such as the Logatchev field on the Mid-Atlantic Ridge (Nakagawa et al., 2005; Hügler et al., 2010), Vailulu seamount in the Samoa and submarine volcanoes on the Kermadec Arc (Hodges and Olson, 2009).
A second major group of epsilonproteobacterial sequences was related to Sulfurospirillum spp. ( $90.8 \%$ average similarity), and clustered outside of the Sulfurospirillum group, constituting 13.6 and $5.8 \%$ of the two libraries respectively (Figure 5 
Table 2 | Sequenced clones, top blast hits to the non-redundant database (closet relative) and best hit among cultured bacteria (closest cultured relative).

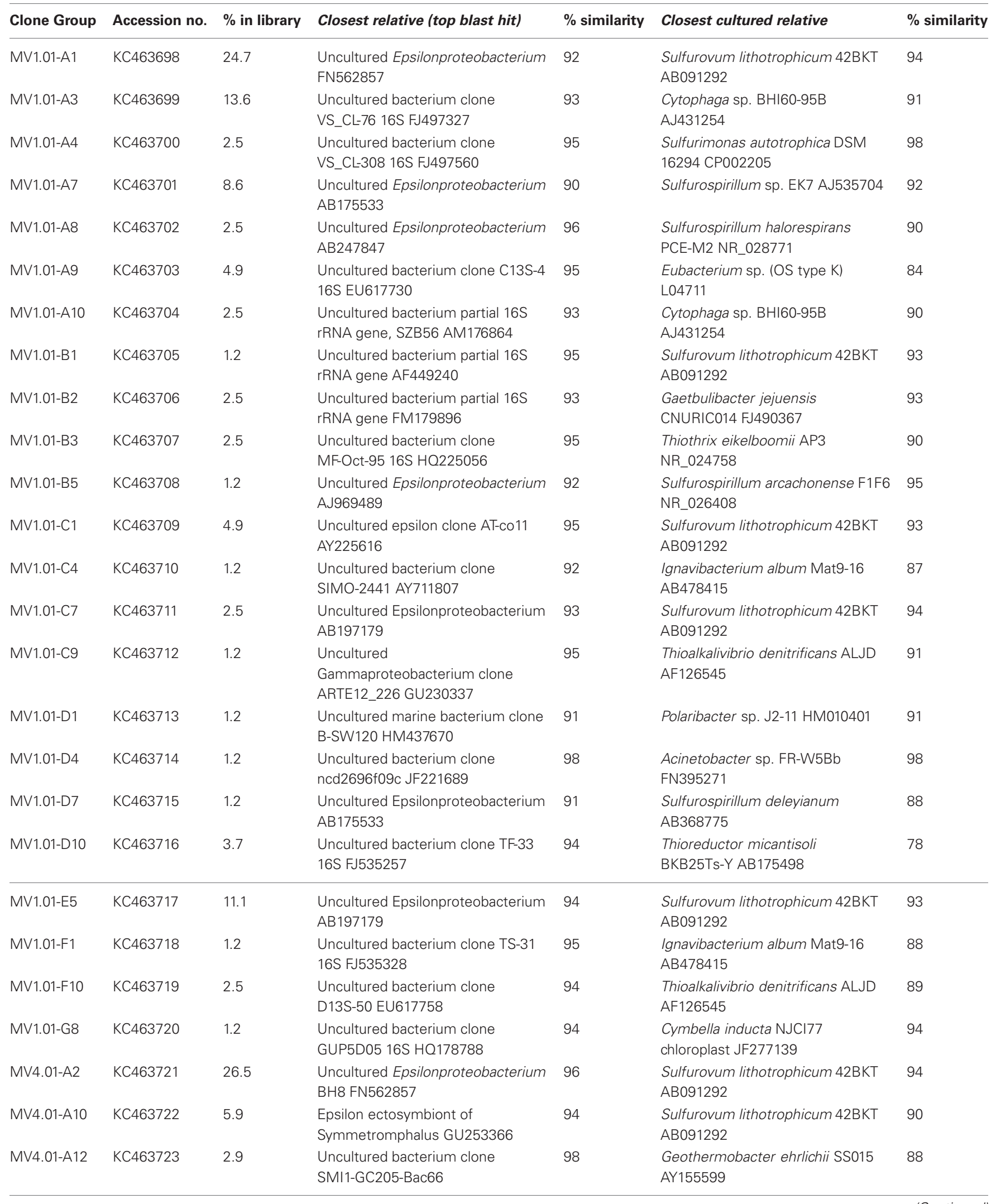


Table 2 | Continued

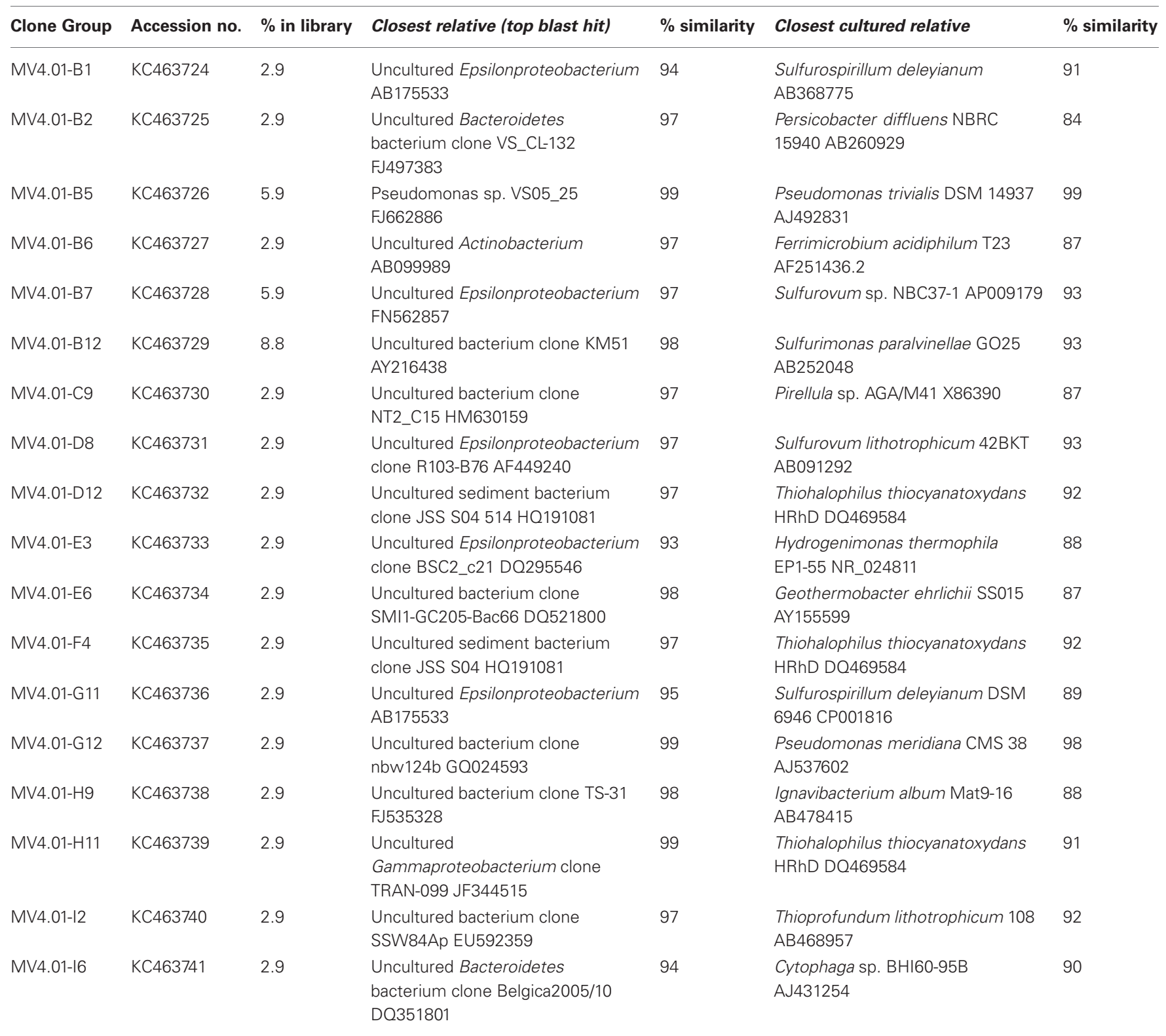

and Table 2). Clones closely related to the Epsilonproteobacterium Sulfurimonas authotrophica were found exclusively in library MV1 (2.5\% of the library sequences), while sequences related to Sulfurimonas paralvinellae constituted $8.8 \%$ of the MV4 library (93\% similarity).

Sequences related to the Gammaproteobacteria constituted the second largest group in the MV4 library and were mainly related to Pseudomonas spp. and members of the Thioalophilus/Thioprofundum cluster (98.5 and $91.7 \%$ average similarity, respectively) constituting $20.6 \%$ of the clones sequenced from this library. In the library from MV1, the Gammaproteobacteria-related sequences were related to Thioalkalivibrio denitrificans and Thiothrix eikelboomii (average similarity $90 \%$ ), constituting only $6.2 \%$ of the library. The remaining gammaproteobacterial clones were associated with Acinetobacter sp. FR-W5Bb (98\% similarity, 1.2\% of the library) and a cluster that included clones MV1.01-C9 and MV1.01-F10, related to Thioalkalivibrio denitrificans (90\% average similarity, $3.7 \%$ of the library, Figure 5 and Table 2).

Sequences related to the Flavobacteria-Bacteroides-Cytophaga cluster were the second major group in library MV1, with an average similarity of $90 \%$ to Cytophaga sp. BHI60-95B (constituting $16 \%$ of the clones in the library). Sequences related to the same species were also found in library MV4 (5.9\% of the library). Unique sequences related to the Flavobacterium Gaetbulibacter jejuensis and Polaribacter sp. j2-11 were present at station MV1 (93 and 91\% similarity, respectively). Deltaproteobacteria were represented in library MV4 
by sequences related to Geothermobacter ehrlichii $(87.5 \%$ similarity, $5.8 \%$ of the clones in the library). MV1 sequences related to the Deltaproteobacteria represented 5\% of the clones in this library and were associated to Eubacterium sp. OS (84\% similarity).

Clones related to the Ignavibacterium album (87.7\% similarity on average) were retrieved from both libraries, MV1 and MV4.

Despite the lower number of clone sequenced at station MV4, computed Chaol diversity estimate indicated that diversity at MV4 was higher than MV1 (Chao1, 63.7 \pm 22 and $28.8 \pm 4.2$ respectively). This can be also inferred from the slope visible on the rarefaction curves computed for both libraries (Figure 6).

\section{DISCUSSION}

Shallow-water hydrothermal vents are distributed worldwide and, while understudied relative to their deep-sea counterparts, they represent unique ecosystems where primary productivity is supported both by chemosynthesis and photosynthesis (Tarasov et al., 2005). In this study, we investigated the abundance, biomass, community structure and diversity of the prokaryotic community at a shallow-water hydrothermal vent in Paleochori Bay, Milos island, Greece (Figure 1).

Prokaryotic abundance was as high as $2.7 \pm 1.1 \times 10^{8}$ cells $\mathrm{g}^{-1}$, with average values comparable to those reported in previous studies of the same area and other shallow-water hydrothermal systems, as well as at deep-sea vents (Figure 2A; Sievert et al., 1999b, 2000a,b; Nakagawa et al., 2005; Manini et al., 2008; Williamson et al., 2008; Maugeri et al., 2009, 2010). Prokaryotic abundance decreased with depth in the sediments at all stations, a general trend previously reported for shallow-water marine sediments (Molari et al., 2012). In contrast, prokaryotic abundance increased toward the periphery of the vent (Figure 2A). Prokaryotic biomass followed similar spatial patterns, with higher values at the surface $(0-1 \mathrm{~cm})$ and at station MV4 (Figure 2B). A previous report of the Milos vents indicated that deeper sediments tend to be hotter (Sievert et al., 2000b), while we

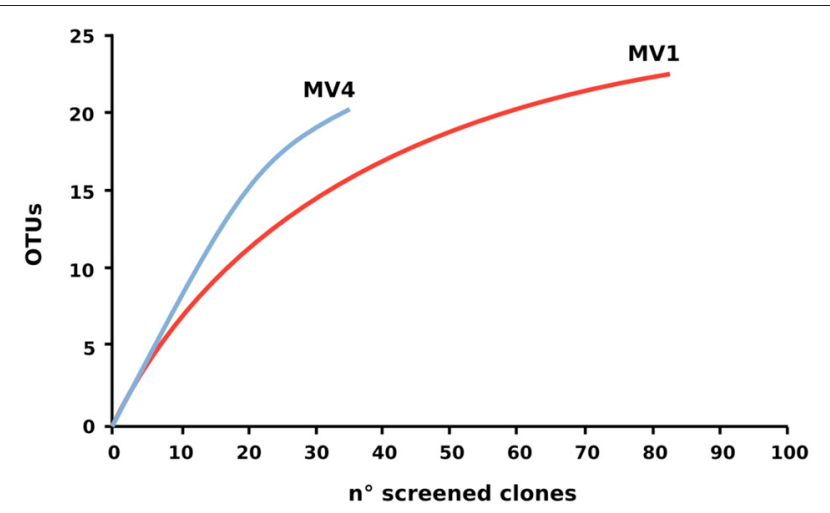

FIGURE 6 | Rarefaction curve of the 16S rRNA gene libraries. Rarefaction curves were computed using Rarefaction software (http://www2.biology.ualberta.ca/jbrzusto/rarefact.php). observed that surface sediments along the transect became gradually cooler at the periphery of the vent (Table 1). Hence, it appears that temperature and prokaryotic biomass are inversely correlated (Figure 2, Pearson moment correlation $r=0.617$, $p<0.05)$.

Biopolymeric organic carbon (BPC), as well as proteins, decreased along the transect from the center (MV1) to the periphery of the vent (MV4), while carbohydrates and lipids remained fairly stable (Table 1). In contrast, phytopigments (CPE) followed an opposite pattern, increasing along the transect from MV1 to MV4 (Table 1). The highest concentrations of proteins and lowest concentration of CPE were measured at station F12 (yellow sediments, temperature $34^{\circ} \mathrm{C}$; Table 1 ). The increasing concentration of $\mathrm{CPE}$ as the sediment temperature decreases implies an increase of phototrophic organisms in the lower temperature regions of the vent system, probably due by the presence of previously described diatoms and cyanobacteria mats in the outer rings of similar vents (Thiermann et al., 1997). This is consistent with the general notion that photoautotrophs are less tolerant to elevated temperatures than chemoautotrophic or chemoheterotrophic microorganisms (Madigan et al., 2012). These findings suggest a gradual enrichment of phototrophic organisms along the decreasing thermal gradient. While BPC and proteins decreased along the transect from MV1 to MV4, prokaryotic abundance and biomass increased (Table $\mathbf{1}$ and Figures 2A,B) and no significant correlation was found among the two parameters (Pearson moment correlation $r=-0.214$, $p>0.05)$. Since the transect was relatively short and all sampling stations were at the same depth, it is safe to assume that the input of organic matter from the water column and lateral advection was constant for all stations. We hypothesize that the decreasing prokaryotic biomass in the hottest section of the vent may lead to a decrease in carbon consumption, which is reflected in the higher concentration of measurable proteins and BPC. This hypothesis implies that temperature, rather than trophic resources, mainly controls the distribution of prokaryotes in this system.

Bacterial diversity, investigated by DGGE profiles, showed that the main DGGE banding pattern was highly conserved, while the highest number of unique bands was obtained from the 35 and $10-15 \mathrm{~cm}$ depth profiles at station MV1 (Figure 3). In total, 30 unique bands with distinct electrophoretic mobility were obtained. As expected, the DGGE analysis highlights the presence of distinct bacterial populations in surface and deeper sediments, which likely reflect different thermal and redox regimes (Figure 3). Similar findings have been reported for a variety of environments, including shallow-water and deep-sea hydrothermal vents (Moyer et al., 1995; Sievert et al., 1999b, 2000a; Manini et al., 2008).

Previous studies of the Paleochori Bay vents based on DGGE and fingerprinting analyses reported a population dominated by the Cytophaga-Flavobacteria-Bacteroides cluster, Gammaproteobacteria of the genus Thiomicrospira and Epsilonproteobacteria of the genus Arcobacter (Brinkhoff et al., 1999; Sievert et al., 1999a, 2000a). Here, we integrated fingerprinting, sequencing and phylogenetic analyses to assess the bacterial diversity of the shallow-water vent ecosystems of Milos 
island. Our survey of the bacterial 16S rRNA gene sequences of the surface sediments of stations MV1 and MV4 showed that Epsilonproteobacteria were the most represented class in both libraries. Epsilonproteobacteria are well adapted to sulfidic conditions and are commonly detected in environmental surveys of geothermal environments, as well as isolated as pure cultures from deep-sea hydrothermal vents (Campbell et al., 2006; Sievert and Vetriani, 2012). In contrast, Gammaproteobacteria constituted only 7 and $20 \%$ of the MV1 and MV4 clone libraries, respectively. It is worth noting that the relative abundance of gammaproteobacterial clones increased from the center to the periphery of the vent (Figure 4). The Epsilon- to Gammaproteobacteria ratio decreased accordingly, from 8.8 at station MV1 to 2.9 at station MV4. Overall, the expected diversity, calculated as Chaol and rarefaction analyses (Figure 6), appeared to be higher at MV4. Sievert et al. (1999a) reached a similar conclusion, as they found that the microbial diversity based on DGGE profiles was higher at the periphery of the vent. Despite this, the beta-diversity within the transect appeared to be relatively low as cloned sequences retrieved from both MV1 and MV4 were closely related (Figure 5).

Phylogenetic analysis showed a large number of the sequences retrieved from both libraries were placed in the Sulfurovum cluster, although the average similarity of the clones generated in this study to the type strain, Sulfurovum lithotrophicum, was only 93\% (Figure 5). S. lithotrophicum is a sulfur-oxidizing Epsilonproteobacterium isolated from deep-sea hydrothermal sediments of the Okinawa trough (Inagaki et al., 2004) and it has since been identified in deep-sea vent communities worldwide (Campbell et al., 2006; Huber et al., 2007; Tokuda et al., 2007; Huber et al., 2010). The identification of Sulfurovumrelated clones in the Milos vents extended the distribution of this group of Epsilonproteobacteria to shallow-water hydrothermal systems. Currently, all the cultured Epsilonproteobacteria isolated from geothermal environments are chemolithoauthotrophs, although some of these bacteria have the ability to use one-carbon compounds (and in some rare cases complex organic carbon compounds; Campbell et al., 2006; Sievert and Vetriani, 2012). Given the phylogenetic distance between the Epsilonproteobacteria identified in this study and both cultured and uncultured relatives, it is possible that the shallow-water hydrothermal vents of Milos harbor members of the Epsilonproteobacteria with novel metabolic characteristics. One interesting hypothesis is that such Epsilonproteobacteria might be mixotrophic or facultatively heterotrophic. Herrmann et al. (2010) and Hubert et al. (2012) formulated similar hypotheses after detecting Epsilonproteobacteria in a benzene-degrading enrichment culture and in discharge waters collected from an oil sands reservoir, respectively. An effort to use alternative strategies to culture and isolate key members of the epsiloproteobacterial community is needed to understand their physiology and metabolism, and ultimately elucidate their role in these ecosystems.

A large number of the sequences retrieved in this study have low similarity to currently cultured bacterial strains (on average $90.1 \%$ similarity), while only four sequences (two for each library, $12.5 \%$ of the total investigated sequences) had similarities over 97\%, a value considered as cut-off for closely related species/strains (Rossello-Mora and Amann, 2001). The nonredundant database indicated that the closest relatives to the Milos sequences were clones retrieved in the course of microbial diversity surveys of deep-sea hydrothermal vents (Lopez-Garcia et al., 2003; Nakagawa et al., 2005; Hügler et al., 2010), coldseeps (Wegener et al., 2008) and seamounts (Hodges and Olson, 2009). However, the average similarity with those sequences was rather low (93.6 and 96.7\% for MV1 and MV4, respectively). This was particularly true for station MV1, where the average similarity between cultured and uncultured relatives was comparable (Table 2). This suggests that the Milos shallow-water hydrothermal vents harbor previously undiscovered taxa, and raises questions about the physiology and metabolism of the Bacteria at this site. Aside from temperature, the quantity and quality of organic matter found at the Milos vent (Table 1) are likely a key factor in selecting for heterotrophic or facultative heterotrophic bacteria. This observation is supported by the abundance of members of the Cytophaga-Flavobacteria-Bacteroides (CFB) cluster in the libraries (Figure 4). Since all cultured members of the CFB are heterotrophs, it is reasonable to speculate that the Milos CFB have a similar metabolism.

None of the 16S rRNA gene sequences identified in this study were related to the newly described genus Galenea, isolated from the same sediment samples (Giovannelli et al., 2012). In contrast to previous studies, none of the gammaproteobacterial 16S rRNA gene sequences were related to the genus Thiomicrospira, and none of the epsilonproteobacterial sequences were related to the genus Arcobacter, both of which were previously reported to be abundant in the Milos vents (Brinkhoff et al., 1999; Sievert et al., 1999b, 2000a). This suggests that spatial and/or temporal differences in the composition of the microbial communities of these vents could be enormous. Shallow-water hydrothermal vents are characterized by fluctuating conditions with elevated temporal and spatial variability of oxygen, salinity, composition of fluids, and venting regimes (Wenzhöfer et al., 2000), and they are furthermore affected by weather conditions, swell, tides and currents. Such variability creates microniches and high spatial and temporal heterogeneity, possibly leading to an increase of the overall community variability and gamma-diversity.

In conclusion, we showed that prokaryotic abundances at the shallow-water vents of Milos island are comparable to those reported in other shallow-water and deep-sea hydrothermal systems. Temperature appears to be the main driving factor in controlling prokaryotic distribution in proximity of the vent and photoautotrophy seems to increase in the lower temperature regions of the vent system. For the first time, Sulfurovum-related sequences were found in shallow-water hydrothermal sediments, which underscores their possible relevance in the microbial communities of both shallow-water and deep-sea hydrothermal vents. The Milos shallow-water hydrothermal vent investigated in this study harbors previously undescribed and unexpected diversity, as most of the sequences retrieved had a very low similarity to previously reported ones. 
This may be due to the abundance of organic matter in these systems, which may support Epsilonproteobacteria with novel metabolic characteristics. Further attempts to isolate key species in those ecosystems will be important to shed light on their ecology and evolution and to better understand these environments.

\section{REFERENCES}

Bach, W., Edwards, K., Hayes, J., Huber, J., Sievert, S., and Sogin, M. (2006). Energy in the dark: fuel for life in the deep ocean and beyond. Eos 87, 73-78. doi: 10.1029/2006EO070002

Baross, J. A., and Hoffman, S. E. (1985). Submarine hydrothermal vents and associated gradient environments as sites for the origin and evolution of life. Orig. Life Evol. B. 15, 327-345. doi: 10.1007/BF01808177

Bligh, E. G., and Dyer, W. J. (1959). A rapid method of total lipid extraction and purification. Can. J. Biochem. Physiol. 37, 911-917. doi: 10.1139/059-099

Botz, R., Stoben, D., Winckler, G., Bayer, R., Schmitt, M., and Faber, E. (1996). Hydrothermal gases offshore Milos Island, Greece. Chem. Geol. 130, 161-173. doi: 10.1016/0009-2541(96)00023-X

Brinkhoff, T., Sievert, S. M., Kuever, J., and Muyzer, G. (1999). Distribution and diversity of sulfur-oxidizing Thiomicrospira spp. at a shallowwater hydrothermal vent in the Aegean Sea (Milos, Greece). Appl. Environ. Microbiol. 65, 3843-3849.

Campbell, B. J., Engel, A. S., Porter, M. L., and Takai, K. (2006). The versatile epsilon-proteobacteria: key players in sulphidic habitats. Nat. Rev. Microbiol. 4, 458-468. doi: 10.1038/nrmicrol414

Chun, J., Lee, J. H., Jung, Y., Kim, M., Kim, S., Kim, B. K., et al. (2007). EzTaxon: a web-based tool for the identification of prokaryotes based on $16 \mathrm{~S}$ ribosomal RNA gene sequences. Int. J. Syst. Evol. Micr. 57, 2259-2261. doi: 10.1099/ijs.0.64915-0

Comita, P. B., Gagosian, R. B., and Williams, P. M. (1984). Suspended particulate organic material from hydrothermal vent waters at 21 N. Nature 307, 450-453. doi: 10.1038/307450a0

Dando, P., Aliani, S., Arab, H., Bianchi, C., Brehmer, M., Cocito, S., et al. (2000). Hydrothermal studies in the Aegean Sea. Phys. Chem. Earth B. Hydrol. Oceans Atmos. 25, 1-8. doi: 10.1016/S1464-1909(99)00112-4

Dando, P., Hughes, J., Leahy, Y., Niven, S., Taylor, L., and Smith, C. (1995). Gas venting rates from submarine hydrothermal areas around the island of Milos, Hellenic Volcanic Arc. Cont. Shelf Res. 15, 913-929. doi: 10.1016/0278-4343 (95)80002-U

Danovaro, R., Manini, E., and Dell'anno, A. (2002). Higher abundance of bacteria than of viruses in deep Mediterranean sediments. Appl. Environ. Microbiol. 68, 1468-1472. doi: 10.1128/AEM.68. 3.1468-1472.2002

Fabiano, M., Danovaro, R., and Fraschetti, S. (1995). A three-year time series of elemental and biochemical composition of organic matter in subtidal sandy sediments of the Ligurian Sea (northwestern Mediterranean). Cont. Shelf Res. 15, 1453-1469. doi: 10.1016/02784343(94)00088-5

Fitzsimons, M., Dando, P., Hughes, J., Thiermann, F., Akoumianaki, I., and Pratt, S. (1997). Submarine hydrothermal brine seeps off Milos, Greece. Observations and geochemistry. Mar. Chem. 57, 325-340. doi: 10.1016/S0304-4203(97)00021-2

Fry, J. C. (1990). 2 Direct Methods and Biomass Estimation. Methods Microbiol. 22, 41-85. doi: 10.1016/S0580-9517(08)70239-3

Gerchakov, S. M., and Hatcher, P. G. (1972). Improved technique for analysis of carbohydrates in sediments. Limnol. Oceanogr. 17, 938-943. doi: 10.4319/lo.1972.17.6. 0938

Giovannelli, D., Grosche, A., Starovoytov, V., Yakimov, M., Manini, E., and Vetriani, C. (2012). Galenea microaerophila gen. nov., sp. nov., a mesophilic, microaerophilic, chemosynthetic, thiosulfate-oxidizing bacterium isolated from a shallow water hydrothermal vent. Int. J. Syst. Evol. Microbiol. 62, 3060-3066. doi: 10.1099/ijs.0.040808-0

Gouy, M., Guindon, S., and Gascuel, O. (2010). SeaView version 4: a multiplatform graphical user interface for sequence alignment and phylogenetic tree building. Mol. Biol. Evol. 27, 221-224. doi: 10.1093/molbev/msp259

Hartree, E. (1972). Determination of protein: a modification of the Lowry method that gives

\section{ACKNOWLEDGMENTS}

The authors wish to thank the Captain and Crew of $\mathrm{R} / \mathrm{V}$ Urania for their assistance in sampling operation. This work has been supported by the InterRidge Student and Postdoctoral Fellowships 2011 to Donato Giovannelli and NSF grants MCB 08-43678 and OCE 11-24141 to Costantino Vetriani.

a linear photometric response. Anal. Biochem. 48, 422-427. doi: 10.1016/0003-2697(72)90094-2

Herrmann, S., Kleinsteuber, S., Chatzinotas, A., Kuppardt, S., Lueders, T., Richnow, H.-H., et al. (2010). Functional characterization of an anaerobic benzene-degrading enrichment culture by DNA stable isotope probing. Environ. Microbiol. 12, 401-411. doi: $10.1111 / \mathrm{j} .1462$ 2920.2009.02077.x

Hodges, T. W., and Olson, J. B. (2009). Molecular comparison of bacterial communities within ironcontaining flocculent mats associated with submarine volcanoes along the Kermadec Arc. Appl. Environ. Microbiol. 75, 1650-1657. doi: 10.1128/AEM.01835-08

Huber, J. A., Cantin, H. V., Huse, S. M., Mark Welch, D. B., Sogin, M. L., and Butterfield, D. A. (2010). Isolated communities of Epsilonproteobacteria in hydrothermal vent fluids of the Mariana Arc seamounts. FEMS Microbiol. Ecol. $73,538-549$.

Huber, J. A., Welch, D. B. M., Morrison, H. G., Huse, S. M., Neal, P. R., Butterfield, D. A., et al. (2007). Microbial population structures in the deep marine biosphere. Science 318, 97-100. doi: 10.1126/science.1146689

Huber, T., Faulkner, G., and Hugenholtz, P. (2004). Bellerophon: a program to detect chimeric sequences in multiple sequence alignments. Bioinformatics 20, 2317-2319. doi: 10.1093/ bioinformatics/bth226

Hubert, C. R., Oldenburg, T. B. P., Fustic, M., Gray, N. D., Larter, S. R., Penn, K., et al. (2012). Massive dominance of Epsilonproteobacteria in formation waters from a Canadian oil sands reservoir containing severely biodegraded oil. Environ. Microbiol. 14, 387-404. doi: 10.1111/j.1462-2920. 2011.02521.x

Hügler, M., Gartner, A., and Imhoff, J. F. (2010). Functional genes as markers for sulfur cycling and $\mathrm{CO} 2$ fixation in microbial communities of hydrothermal vents of the Logatchev field. FEMS Microbiol. Ecol. 73, 526-537.
Inagaki, F., Takai, K., Nealson, K. H., and Horikoshi, K. (2004). Sulfurovum lithotrophicum gen. nov., sp. nov., a novel sulfuroxidizing chemolithoautotroph within the epsilon-Proteobacteria isolated from Okinawa Trough hydrothermal sediments. Int. J. Syst. Evol. Microbiol. 54, 1477-1482. doi: 10.1099/ijs.0.03042-0

Jannasch, H. (1985). Review lecture: the chemosynthetic support of life and the microbial diversity at deepsea hydrothermal vents. Proc. Royal Soc. Lond. B 225, 277-297. doi: 10.1098/rspb.1985.0062

Larkin, M., Blackshields, G., Brown, N., Chenna, R., Mcgettigan, P., Mcwilliam, H., et al. (2007). Clustal $\mathrm{W}$ and Clustal $\mathrm{X}$ version 2.0. Bioinformatics 23, 2947-2948. doi: 10.1093/bioinformatics/btm404

Lonsdale, P. (1977). Clustering of suspension-feeding macrobenthos near abyssal hydrothermal vents at oceanic spreading centers. Deep Sea Res. 24, 857-863. doi: 10.1016/0146-6291(77)90478-7

Lopez-Garcia, P., Duperron, S., Philippot, P., Foriel, J., Susini, J., and Moreira, D. (2003). Bacterial diversity in hydrothermal sediment and epsilonproteobacterial dominance in experimental microcolonizers at the Mid-Atlantic Ridge. Environ. Microbiol. 5, 961-976. doi 10.1046/j.1462-2920.2003.00495.x

Madigan, M. T., Martinko, J. M., Stahl, D. A., and Clark, D. P. (2012). in Brock Biology of Microorganisms, 13th Edn. (Pearson Education Inc.), 138-139.

Maniatis, T. (1989). Molecular Cloning: A Laboratory Manual/J. Sambrook, EF Fritsch, T. Maniatis. New York, NY: Cold Spring Harbor Laboratory Press.

Manini, E., Luna, G., Corinaldesi, C., Zeppilli, D., Bortoluzzi, G., Caramanna, G., et al. (2008). Prokaryote diversity and virus abundance in shallow hydrothermal vents of the Mediterranean Sea (Panarea Island) and the Pacific Ocean (North Sulawesi-Indonesia). Microb. Ecol. 55, 626-639. doi: 10.1007/s00248-007-9306-2

Marsh, J. B., and Weinstein, D. B. (1966). Simple charring method for 
determination of lipids. J. Lipid Res. 7, 574-576.

Martin, W., Baross, J., Kelley, D., and Russell, M. J. (2008). Hydrothermal vents and the origin of life. Nat. Rev. Microbiol. 6, 805-814.

Maugeri, T. L., Lentini, V., Gugliandolo, C., Cousin, S., and Stackebrandt, E. (2010). Microbial Diversity at a Hot, Shallow-Sea Hydrothermal Vent in the Southern Tyrrhenian Sea (Italy). Geomicrobiol. J. 27, 380-390. doi: 10.1080/0149045090 3451518

Maugeri, T. L., Lentini, V., Gugliandolo, C., Italiano, F., Cousin, S., and Stackebrandt, E. (2009). Bacterial and archaeal populations at two shallow hydrothermal vents off Panarea Island (Eolian Islands, Italy). Extremophiles 13, 199-212. doi: 10.1007/s00792-008-0210-6

Molari, M., Giovannelli, D., D'errico, G., and Manini, E. (2012). Factors influencing prokaryotic community structure composition in subsurface coastal sediments. Estuar. Coast. Shelf Sci. 97, 141-148. doi: 10.1016/j.ecss.2011.11.036

Moyer, C. L., Dobbs, F. C., and Karl, D. M. (1995). Phylogenetic diversity of the bacterial community from a microbial mat at an active, hydrothermal vent system, Loihi Seamount, Hawaii. Appl. Environ. Microbiol. 61, 1555-1562.

Nakagawa, S., and Takai, K. (2008). Deep-sea vent chemoautotrophs: diversity, biochemistry and ecological significance. FEMS Microbiol. Ecol. 65, 1-14. doi: 10.1111/j.15746941.2008.00502.x

Nakagawa, S., Takai, K., Inagaki, F., Hirayama, H., Nunoura, T., Horikoshi, K., et al. (2005). Distribution, phylogenetic diversity and physiological characteristics of epsilon-Proteobacteria in a deepsea hydrothermal field. Environ. Microbiol. 7, 1619-1632. doi: 10.1111/j.1462-2920.2005.00856.x

Nisbet, E., and Fowler, C. (1996). The hydrothermal imprint on life: did heat-shock proteins, met- alloproteins and photosynthesis begin around hydrothermal vents? Geol. Soc. Lond. Spec. Publ. 118, 239-251. doi: 10.1144/GSL.SP. 1996.118.01.15

Nisbet, E., and Sleep, N. (2001). The habitat and nature of early life. Nature 409, 1083-1091. doi: $10.1038 / 35059210$

Perriere, G., and Gouy, M. (1996). WWW-query: an on-line retrieval system for biological sequence banks. Biochimie 78, 364-369. doi: 10.1016/0300-9084(96)84768-7

Plante-Cuny, M. R. (1974). Evaluation par spectrophotométrie des teneurs en chlorophylle a fonctionnelle et en phéopigments des substrats meubles marins. (Nosy-Bé : ORSTOM).

Rossello-Mora, R., and Amann, R. (2001). The species concept for prokaryotes. FEMS Microbiol. Rev. 25, 39-67. doi: 10.1016/S0168-6445(00)00040-1

Schneider, C. A., Rasband, W. S., and Eliceiri, K. W. (2012). NIH Image to ImageJ: 25 years of image analysis. Nat. Methods 9, 671-675. doi: 10.1038/nmeth.2089

Sievert, S. M., Brinkhoff, T., Muyzer, G., Ziebis, W., and Kuever, J. (1999a). Spatial heterogeneity of bacterial populations along an environmental gradient at a shallow submarine hydrothermal vent near Milos Island (Greece). Appl. Environ. Microbiol. 65, 3834-3842.

Sievert, S. M., Brinkhoff, T., Muyzer, G., Ziebis, W., and Kuever, J. (1999b). Spatial heterogeneity of bacterial populations along an environmental gradient at a shallow submarine hydrothermal vent near Milos Island (Greece). Appl. Environ. Microbiol. 65, 3834-3842.

Sievert, S. M., Kuever, J., and Muyzer, G. (2000a). Identification of $16 \mathrm{~S}$ ribosomal DNA-defined bacterial populations at a shallow submarine hydrothermal vent near Milos Island (Greece). Appl. Environ. Microbiol. 66, 3102-3109. doi: 10.1128/AEM.66.7.3102-3109.2000

Sievert, S. M., Ziebis, W., Kuever, J., and Sahm, K. (2000b). Relative abun- dance of Archaea and Bacteria along a thermal gradient of a shallowwater hydrothermal vent quantified by rRNA slot-blot hybridization. Microbiology 146, 1287-1293.

Sievert, S. M., and Vetriani, C. (2012). Chemoautotrophy at deep-sea vents: past, present, and future. Oceanography 25, 218-233. doi: 10.5670/oceanog.2012.21

Staley, J. T., and Reysenbach, A. L. (2002). Biodiversity of Microbial Life: Foundation of Earth's Biosphere. New York, NY: Wiley-Liss.

Tarasov, V., Gebruk, A., Mironov, A., and Moskalev, L. (2005). Deepsea and shallow-water hydrothermal vent communities: two different phenomena? Chem. Geol. 224, 5-39. doi: 10.1016/j.chemgeo.2005.07.021

Thiermann, F., Akoumianaki, I., Hughes, J., and Giere, O. (1997). Benthic fauna of a shallow-water gaseohydrothermal vent area in the Aegean Sea (Milos, Greece). Mar. Biol. 128, 149-159. doi: 10.1007/s002270050078

Tokuda, G., Yamada, A., Nakano, K., Arita, N. O., and Yamasaki, H. (2007). Colonization of Sulfurovum sp. on the gill surfaces of Alvinocaris longirostris, a deep-sea hydrothermal vent shrimp. Mar. Ecol. 29, 106-114. doi: 10.1111/j.1439-0485.2007.00211.x

Underwood, A. (1991). Beyond BACI experimental designs for detecting human environmental impacts on temporal variations in natural populations. Mar. Freshw. Res. 42, 569-587. doi: 10.1071/ MF9910569

Valsami-Jones, E., Baltatzis, E., Bailey, E., Boyce, A., Alexander, J., Magganas, A., et al. (2005). The geochemistry of fluids from an active shallow submarine hydrothermal system: Milos island, Hellenic Volcanic Arc. J. Volcanol. Geother. Res. 148, 130-151. doi: 10.1016/j.jvolgeores.2005.03.018

Wegener, G., Niemann, H., Elvert, M., Hinrichs, K. U., and Boetius, A. (2008). Assimilation of methane and inorganic carbon by microbial communities mediating the anaerobic oxidation of methane. Environ. Microbiol. 10, 2287-2298. doi: 10.1111/j.1462-2920.2008.01653.x

Weisburg, W. G., Barns, S. M., Pelletier, D. A., and Lane, D. J. (1991). 16S ribosomal DNA amplification for phylogenetic study. J. Bacteriol. 173, 697-703.

Wenzhöfer, F., Holby, O., Glud, R. N., Nielsen, H. K., and Gundersen, J. K. (2000). In situ microsensor studies of a shallow water hydrothermal vent at Milos, Greece. Mar. Chem. 69, 43-54. doi: 10.1016/S0304-4203(99)00091-2

Williamson, S. J., Cary, S. C., Williamson, K. E., Helton, R. R., Bench, S. R., Winget, D., et al. (2008). Lysogenic virushost interactions predominate at deep-sea diffuse-flow hydrothermal vents. Isme. J. 2, 1112-1121. doi: 10.1038/ismej.2008.73

Conflict of Interest Statement: The authors declare that the research was conducted in the absence of any commercial or financial relationships that could be construed as a potential conflict of interest.

Received: 11 January 2013; accepted: 18 June 2013; published online: 08 July 2013.

Citation: Giovannelli D, d'Errico G, Manini E, Yakimov $M$ and Vetriani C (2013) Diversity and phylogenetic analyses of bacteria from a shallowwater hydrothermal vent in Milos island (Greece). Front. Microbiol. 4:184. doi: 10.3389/fmicb.2013.00184

This article was submitted to Frontiers in Extreme Microbiology, a specialty of Frontiers in Microbiology.

Copyright () 2013 Giovannelli, d'Errico, Manini, Yakimov and Vetriani. This is an open-access article distributed under the terms of the Creative Commons Attribution License, which permits use, distribution and reproduction in other forums, provided the original authors and source are credited and subject to any copyright notices concerning any third-party graphics etc. 